\title{
Yatılı Okullarda Görev Yapan Öğretmenlerin İş Doyumlarının İncelenmesi: Nitel Bir Araştırma
}

\author{
Oğuzhan YILDIRIM \\ Millî Eğitim Bakanlı̆ğ \\ oguzhanyildirim.pdr@gmail.com \\ ORCID ID: 0000-0002-8174-9640
}

\begin{tabular}{lrr} 
Araştırma Makalesi & DOI: $10.31592 /$ aeusbed.686646 \\
\hline Geliş Tarihi: 08.02.2020 & Revize Tarihi: 09.11 .2020 & Kabul Tarihi: 10.11 .2020
\end{tabular}

\section{Atıf Bilgisi}

Yıldırım, O. (2020). Yatılı okullarda görev yapan öğretmenlerin iş doyumlarının incelenmesi: Nitel bir araştırma. Ahi Evran Üniversitesi Sosyal Bilimler Enstitüsü Dergisi, 6(3), 828-841.

\section{Öz}

$\mathrm{Bu}$ araştırmada yatılı okullarda görev yapan öğretmenlerin iş doyumlarının incelenmesi amaçlanmıştır. Araştırma nitel araştırma yöntemlerinden fenomenolojik yaklaşıma dayanmaktadır. Araştırmanın çalışma grubunda yer alan katılımcılar amaçlı örnekleme yöntemiyle seçilmiştir. Çalışma grubunda yatılı okullarda görev yapan gönüllü 18 öğretmen yer almıştır. Veri toplama kısmında araştırmacı tarafından hazırlanan 17 sorudan oluşan yarı yapılandırılmış görüşme formu kullanılmıştır. Bu formdan elde edilen veriler içerik analiz yöntemi ile çözümlenmiştir. Yapılan analizler sonucunda; üç tema (Kazanç, Güçlük ve Gelecek Planları) ve bu temalara ilişkin dokuz alt tema oluşturulmuştur. Araştırma sonuçlarına göre yatılı okullarda çalışan öğretmenlerin iş doyumlarını etkileyen içsel ve dışsal birçok faktörün olduğu görülmüştür. Bu öğretmenlerin iş doyumlarını düşüren faktörlerin başında gece nöbetleri/belleticilik görevleri, fiziksel yorgunlukları ve sorumlulukları gelmiştir. Bunun yanında okul ortamının aile ortamı samimiyetinde olması ve öğrencilerle olumlu ilişkilerin kurulmasının öğretmenlerin iş doyumlarını arttıran faktörler olduğu anlaşılmıştır. Araştırma sonucunda elde edilen bulgular bu kapsamda çalışmada alanyazı çerçevesinde tartışılmış ve ilgili alanyazına bazı önerilerde bulunulmuştur.

Anahtar Kelimeler: İş doyumu, yatılı okul, nöbet, nitel araştırma.

\section{Investigating Job Satisfaction of Teachers Working in Boarding School: A Qualitative Research}

\begin{abstract}
In this study, it was aimed to examine job satisfaction of teachers working in boarding schools. The study embraced phenomenological research of qualitative design. The study group of the study was determined by purposive sampling method. The study group consisted of 18 volunteer teachers working in boarding schools. In the data collection, a semi-structured interview form consisting of 17 questions prepared by the researcher was used. Content analysis was performed in analyzing the data. As a result of the content analysis, there were three themes (Gain, Difficulty and Future Plans) and nine related sub themes. According to the results of the research, it has been found that there are many internal and external factors affecting the job satisfaction of the teachers working in boarding schools. Night guard duty, fatigue and responsibilities were the main factors that reduced job satisfaction of these teachers. However, the fact that the school is like a family environment and positive relations with the students increased the job satisfaction of the teachers. The results of the study were discussed within the literature and further suggestions were made.
\end{abstract}

Keywords: Job satisfaction, boarding school, guard duty, qualitative research.

\section{Giriş}

Toplumun birçok alanda iyi yetiştirilmiş bireylere ihtiyacı vardır. İnsanların birçok alanda gelişebilmesinin en temel yolu eğitimdir. Eğitimin en büyük aktörleri ise öğretmenlerdir. Toplumun gelişmesi ve ilerlemesinde işini severek yapan, çalışma ortamında huzurlu olan ve iş doyumu yüksek olan öğretmenlerin rolü oldukça büyüktür (Adıgüzel, Karadağ ve Ünsal, 2011; Karakaya-Çiçek ve Çoruk, 2017). Eğitim ile ilgili bugüne kadar birçok bilimsel araştırma yapılmıştır (Bakioğlu ve Göktaş, 2018). Özellikle son yıllarda bilim dünyasındaki gelişmeler incelendiğinde, özellikle beşerî bilimler alanında birey odaklı araştırmaların arttığı gözlemlenmiştir. Birey odaklı bu araştırmaların başında gelen kavramlardan biri de iş doyumu kavramıdır. İş doyumu kavramı ilk olarak 1920'li yıllarda ortaya çıkmış olsa da önemi 1930'dan sonra anlaşılmıştır (Agho, Mueller ve Price, 1993). Locke (1976) iş doyumunu; kişinin işini sevmesi ve performansını beğenmesiyle ortaya hoş ve olumlu duyguların çıkması olarak tanımlar. 
Çalışan bireyin işinden elde ettiği haz ve mutluluk onun iş doyumunu arttırır (Aslan ve Erbay, 2017) İş doyumu kavramı kişinin işi hakkında olumlu duygulara sahip olması anlamına gelir (Robbins ve Judge, 2012). İş doyumu yüksek kişiler daha sağlıklı ve yaşamının birçok alanında daha mutlu olmaktadır (Altınkurt ve Yılmaz, 2014; Gill, 1999). Bireysel ve çevresel birçok faktör iş doyumunu etkilemektedir. Kişinin cinsiyeti, yaşı, sosyal çevresi, kişilik yapısı, eğitim düzeyi medeni durumu ve çalışma ortamından beklentileri iş doyumunu etkileyen bireysel faktörleri oluşturmaktadır. Çevresel faktörler ise alınan maaş, çalışma koşulları, yükselebilme durumu, yöneticiyle ilişsi ve işin niteliğinden oluşmaktadır (Başaran, 2000).

İş doyumunun düşük olması; iş yerindeki verimin düşmesine, işten ayrılmaya, moral bozukluğuna ve çalışanların birbirleri ile kutuplaşmasına neden olmaktadır (Çelikkanat, 2000; Gedik ve Üstüner, 2017). Vroom Beklenti Kuramı'na göre bireyler; kendileri için önemli olan amaçlar doğrultusunda çalıştığında ve olumlu davranışlarının ardından ödül alacaklarını bildiği durumlarda daha yüksek iş doyumuna sahip olabilmektedirler (Okumuş, 2011). İnsanlar yaşamlarının ortalama üçte birini iş ortamında geçirmektedirler. Dolayısıyla fiziksel, sosyal ve ruhsal ihtiyaçlarını iş ortamında da karşılamak isterler. Kişilerin iş hayatında mutlu, verimli ve başarılı olabilmesinin yolu iş doyumunun yüksek olmasından geçmektedir (Keser, 2005).

\section{Öğretmenlerin İş Doyumu}

Eğitim kurumlarında bilgi alışverişinin ve iletişimin sağlıklı bir şekilde sağlanabilmesi için okul ortamının güvene dayalı olmasında fayda vardır. Öğretmenlik mesleğine ilişkin olumsuz tutumların ve eğitim kurumlarındaki iş doyumunun düşük olmasıyla eğitimin kalitesi azalmaktadır (Altunkeser ve Ü̉nal, 2015; İşgör ve Haspolat, 2017). Eğitim ortamındaki iş doyumunun düşük olmas1 eğitimin kalitesine, öğrencilere, öğrenci velilerine ve tüm topluma dolaylı olarak zarar verebilmektedir (Çokluk, 2003, s.109).

Öğretmenler için iş doyumu kavramı öğretmenlerin öğretmenlik mesleğinden duydukları hoşnutluk veya hoşnutsuzluk duygusu olarak ifade edilmektedir (Vural, 2004). Jackson, Schwab ve Schuler (1986) ise öğretmenlerde iş doyumunu etkileyen faktörleri şu şekilde ifade etmiştir: Ekonomik durum, çalışma saatleri, stres, yöneticilerle ilişkiler ve çalışma koşulları. Okul ortamının olumlu bir iklime sahip olmasında, veli-okul-öğretmen iş birliğinin sağlanmasında, öğretmenlerin iş doyumunun artmasında ve dolayısıyla eğitimde verimin, performansın ve huzurun artmasında okul yöneticilerinin de oldukça önemli bir misyonu bulunmaktadır (Çalışkan ve Ayık, 2015; Gökyer, 2011). Tüm bu nedenlerden dolayı okullar; öğretmenlerin iş doyumunu yükseltecek yollar bulma konusunda daha dikkatli ve istekli olmalıdırlar.

Yatılı okullarda görev yapan öğretmenler yalnızca öğretmenlik yapmamaktadır. Bu öğretmenler ayrıca öğrencilerine karşı bir ebeveyn gibi davranmak durumundadır. Bunun sonucunda öğretmenler ile öğrenciler arasında aile bağları oluşmakta ve bu öğrenciler öğretmenlerini rol model olarak görmektedir. Yatılı okullarda çalı̧̧an öğretmenler diğer öğretmenlere göre daha fazla görev ve sorumluluklara sahiptir. Bu öğretmenler; öğrencilerinin ders çalışma motivasyonlarını desteklemekte, öz bakım becerilerini geliştirmekte, boş zamanlarını verimli değerlendirmelerini sağlamakta, öğrencilere yönelik ödül ve ceza sistemi oluşturmakta ve çeşitli sorunlarında yardım etmeye çalışmaktadır (Şenol ve Yıldız, 2009).

Yatılı okullarda çalışan öğretmenlerin tükenmişlik düzeyleri daha yüksektir (Gündüz, 2006). $\mathrm{Bu}$ öğretmenlerin yatılı okullara karşı olumsuz algılara sahip olmasına yol açan faktörlerin başında ekstra sorumluluklara sahip olmaları, okul yöneticileriyle anlaşmazlıklar yaşamaları ve yurtta kalan öğrencilerin olumsuz davranışlar sergilemeleri gelmektedir (İnal ve Sadık, 2011). Ayrıca bu öğretmenlerin duygusal, zihinsel ve fiziksel açıdan yıprandıkları da görülmektedir (Dağlı ve Gündüz, 2008). 


\section{Yatılı Okulların Tarihçesi}

Türkiye'de nüfus dağılımı dengesiz ve dağınıktır. Ulaşımın zor olduğu birçok köy, mezra ve yayla gibi yerleşim yerleri vardır. Özellikle Güneydoğu Anadolu Bölgesi, Doğu Anadolu Bölgesi ve Karadeniz Bölgesinde iklim ve coğrafi açıdan bazı engeller bulunmaktadır. Bu durum da zorunlu eğitim kapsamındaki çocukların okullara devam edememesine neden olmaktadır. Yatılı okulların temeli olan yatılı bölge ortaokulları nüfusun dağınık ve az olduğu yerlerde birbirine yakın köylerdeki öğrencilerin eğitim görmesi için açılan yatılı okullardır (Millî Eğitim Bakanlığı [MEB], 2011). Türkiye'de yatılı okulların açılması Cumhuriyet döneminin ilk yıllarına dayanır. Türkiye Büyük Millet Meclisi'nin açılış konuşmasında Mustafa Kemal Atatürk ilköğretim dönemindeki çocuklar için yatılı okulların açılması gerektiğini ifade etmiştir. Buradan hareketle 1923 ile 1933 yılları arasında maddi imkânı olan illere, 1933 ile 1938 yılları arasında ilçelere, 1940'larda ise merkezi köylere yatılı okullar açılmaya başlanmıştır (Aralpcan, 1998). 2020 y1lı itibariyle 546.290 kapasiteli 3.065 yatılı okul bulunurken bu okullarda 328141 öğrenci öğrenim görmektedir (MEB, 2020).

Türkiye'de yaşanan yoğun göç hareketleri ile politik ve ekonomik faktörler yatılı okulların ortaya çıkmasına neden olan etmenlerden bazılarıdır (Aralpcan, 1998). Köyden kente yaşanan göçün artmasıyla köylerdeki okulların kapanması hızlanmış ve yatılı okullar gibi merkezi okulların açılması ihtiyacı doğmuştur (Sevim, 2001). Yatılı okullarda kalan öğrenciler ailelerinden uzakta yaşamakta ve bu durumun bazı zorluklarını hissetmektedirler. Bundan dolayı yatılı okullarda görev yapan öğretmenlerin sorumlulukları ve farkındalık düzeyleri oldukça önemlidir (MEB, 2010). Bu nedenle yatılı okullarda görev yapan öğretmenlerin iş doyumları diğer okullardaki öğretmenlerin iş doyumlarından daha önemli olabilmektedir. Bu öğretmenlerin belleticilik görevleri de olduğundan geceleri pansiyon nöbetleri tutmakta ve ailesinden ayrı kalan öğrencilerle 24 saat vakit geçirmektedirler (Çelik, 2017). Millî Eğitim Bakanlığına Bağlı Resmi Okullarda Yatılılık, Bursluluk, Sosyal Yardımlar ve Okul Pansiyonları Yönetmeliği'nde yer alan 40.maddeye göre gece pansiyon nöbeti tutan belletici öğretmenlerin sorumlulukları şu şekilde sıralanmıştır: Pansiyonda kalan öğrencilerin ders saatleri dışında eğitimleriyle ilgilenmek ve gerektiğinde derslerine yardımcı olmak, gece bekçilerini ve güvenlik görevlilerini kontrol etmek, etüt aralarında öğrencileri gözetim altında bulundurmak, pansiyonda kalan öğrencilerin yoklamasını yapmak, pansiyona gelen ziyaretçilerle ilgili iş ve işlemleri yürütmek, disiplin olayları ile ilgili iş ve işlemleri yürütmek, hastalanan öğrencilerin durumlarıyla ilgili iş ve işlemleri yürütmek, öğrencilerin ilaçlarının dağıtımıyla ilgili iş ve işlemleri yürütmek, okul yönetimi tarafından verilen görev ve sorumlulukları yerine getirmek (MEB, 2016).

Alanyazın incelendiğinde öğretmenlerin iş doyumunu inceleyen araştırmalar mevcuttur (Arı, 2015; Başaran ve Güçlü, 2018; Çelik, 2017; Demirtaş ve Nacar, 2018; Karakaya-Çiçek ve Çoruh, 2017; Koruklu, Feyzioğlu, Kiremit ve Aladağ, 2013; Y1lmaz ve Aslan, 2018). Ancak yapılan araştırmaların büyük çoğunluğunun nicel araştırma yöntemleriyle yapıldığ 1 görülmektedir. $\mathrm{Bu}$ araştırmada ise eğitim öğretimde yıllardır süregelen önemli bir konu olan yatılı okullar ile bu okullarda görev yapan öğretmenler nitel araştırma yöntemiyle incelenmiştir. Bu araştırmanın amacı yatılı okullarda görev yapan öğretmenlerin iş doyum düzeylerini ayrıntılı olarak incelemektir. Eğitimin başrolü konumunda bulunan öğretmenlerin; okula, mesleğe, öğrencilere, diğer öğretmenlere, okul yöneticilerine ve geleceğe dair duygu, düşünce ve tutumları da araştırma kapsamında incelenmiştir. $\mathrm{Bu}$ araştırmanın yatılı okullar ve bu okullarda görev yapan öğretmenlerin iş doyumları hakkında alanyazına önemli bir katkı sağlayacağı düşünülmektedir.

\section{Yöntem}

Araştırmanın yöntem kısmında araştırma deseni, çalışma grubu, veri toplama araçları, verilerin toplanma ve analiz sürecine ilişkin bilgilere yer verilmiştir.

\section{Araşturma Deseni}

$\mathrm{Bu}$ araştırma yatılı okullarda görev yapan öğretmenlerin mesleklerine yönelik duygu, düşünce ve tutumlarını ortaya koymak amacıyla yapılmıştır. Bu çalışmada nitel araştırma yöntemlerinden 
fenomenolojik bilim deseni kullanılmıştır. Nitel araştırmalarda en fazla karşılaşılan tip olan fenomenolojik desende araştırmacı; insanların kendi bakış açılarından bir fenomeni nasıl anlamlandırdıklarını açıklamaya çalışır. Ayrıca bu desende kişilerin bakış açıları ve deneyimleri incelenir (Johnson ve Christensen, 2014).

\section{Çalışma Grubu}

Araştırmanın çalı̧̧ma grubunu 2018-2019 eğitim öğretim yılında Sivas'a bağlı bir ilçede yer alan yatılı bölge ortaokulu ve yatılı yurdu olan liselerde görev yapan 18 öğretmen oluşturmuştur. $\mathrm{Bu}$ öğretmenler amaçlı örnekleme yöntemiyle belirlenmiştir. Amaçlı örnekleme yöntemi araştırmacının belirli özelliklere sahip kişileri araştırmasına katmasıdır (Johnson ve Christensen, 2014). Öğretmenlerin seçiminde belirlenen özellik; yatılı okullarda görev yapmak ve gece nöbet tutmak olarak belirlenmiştir.

Tablo 1

Çalışma Grubuna İlişkin Demografik Bilgiler

\begin{tabular}{llll}
\hline & & $n$ & $\%$ \\
\hline Cinsiyet & Kadın & 6 & 33 \\
& Erkek & 12 & 66 \\
Eğitim Düzeyi & Lisans & 16 & 83 \\
& Yüksek Lisans & 2 & 17 \\
Çalışı̆ı̆ı Kademe & & & 22 \\
& İlkokul & 4 & 56 \\
& Ortaokul & 10 & 22 \\
\hline Toplam & Lise & 4 & 100 \\
\hline
\end{tabular}

Araştırmaya 6 kadın 12 erkek öğretmen katılmıştır. Bu öğretmenlerden 15'i lisans 3'ü yüksek lisans mezunudur. Katılımeı öğretmenlerin yaşları 22 ile 60, hizmet süreleri ise 1 ile 37 y1l arasında değişmektedir. Çalışma grubunu oluşturan Sınıf, Rehberlik, Türkçe, Fen ve Teknoloji, Matematik, Din Kültürü, Özel Eğitim, Görsel Sanatlar, Bilişim Teknolojileri, Beden Eğitimi, İngilizce ve Sosyal Bilgiler öğretmenlerinin 4'ü ilkokul, 10'u ve 4'ü lisede görev yapmaktadır.

\section{Veri Toplama Araçları}

Çalışmada veri toplama aracı olarak araştırmacı tarafından geliştirilen yarı yapılandırılmış görüşme formu kullanılmıştır. Araştırmada yer alan sorular hazırlanırken konuyla ilgili alanyazındaki araştırmalardan yararlanılmıştır (Çelik, 2017; Gökyer, 2011; İnal ve Sadık, 2014; Karakaya-Çiçek ve Çoruk, 2017). Ardından görüşme formundaki sorular için uzman görüşü alınmış ve tavsiye edilen düzeltmeler yapılmıştır. Görüşme formunda öğretmenlerin yatılı okula, mesleğe, meslektaşlarına ve geleceğe yönelik tutumlarını ölçen toplamda 17 soru bulunmaktadır. Sorulardan bazıları şu şekildedir: "Çalışma koşullarınız hakkında ne düşünüyorsunuz?", "Yatılı okuldaki çalışma ortamınız duygu dünyanızı nasıl etkiliyor?", "Mesleki motivasyon kaynaklarınız nelerdir?", "Yatılı okulda çalışmanın mesleki anlamda artı ve eksileri nelerdir?".

\section{Verilerin Toplanma ve Analiz Süreci}

Verilerin toplanması için okul rehberlik servisinde gerçekleştirilen görüşmeler bir ay sürmüş ve 2018 yılı Aralık ayında tamamlanmıştır. Katılımcılar arasından gönüllü olan 18 öğretmen araştırmaya katılmayı kabul etmiştir. Veri toplama sürecinde araştırmacı tarafından ses kaydı alınmasına izin veren 17 öğretmenden ses kaydı alınmış; ses kaydının alınmasını istemeyen bir ögretmen ise soruları yazılı olarak cevaplandırmıştır. 
Verilerin toplanma aşamasında ses kaydıyla elde edilen veriler araştırmacı tarafindan yazılı hale getirilmiştir. Ardından bu veriler tematik olarak analiz edilmiştir (Braun ve Clarke, 2006). Öğretmenlerin yanıtları kodlanmış ve bu kodlamalar temalar altında toplanmıştır. Ayrıca analiz sürecinde nitel araştırma konusunda uzman kişilerin görüşleri alınmış ve öğretmenlerden katılımc1 teyidi yapılmıştır. Böylece araştırmanın inandırıcılığının arttırılması amaçlanmıştır. Araştırmanın güvenirliği için katılımcılara ait bilgiler açık bir şekilde ifade edilmiş, veri toplama ve veri analizi süreçleri ayrıntılı bir şekilde araştırmada yer almıştır. Araştırmacının tarafsız olması, katılımcıların ses kayıtlarının alınması, verilen cevapların not edilmesi ve katılımcıların cevaplarından alıntılama yapılması gibi yöntemlere de (Creswell, 2014) başvurulmuştur. Araştırmanın geçerliği için; araştırmada alıntılamaların yer almasını içeren düşük çıkarım tanımlayıcıları ve araştırmacının ön yargısına dikkat etmeyi içeren yansıyabilirlik stratejilerine (Johnson ve Christensen, 2014) başvurulmuştur. Araştırmaya katılan öğretmenlerin isimleri yerine isim baş harfleri ve görüşmedeki sıralamaları kod olarak belirlenmiştir. Örneğin görüşme yapılan öğretmenler içinde üçüncü sırada yer alan ve ismi T harfi ile başlayan bir öğretmen (T3) olarak kodlanmıştır.

\section{Bulgular}

Araştırmada elde edilen tema ve alt temalar Tablo 2'de sunulmuştur. Kazanç, Güçlük ve Gelecek Planları olmak üzere üç tema oluşturulmuştur. Kazanç temasına ait Fırsat, Motivasyon, İlişki ve Tecrübe; Güçlük temasına ait Olumsuz Duygular ve Sorumluluk; Gelecek Planları temasına ait Okul Değiştirme, Meslek Değiştirme ve Emeklilik alt temaları yer almıştır. Elde edilen veriler üzerinde içerik analizi yapılmıştır. Bu bölümde katılımcıların verdikleri bazı yanıtlara doğrudan yer verilerek alıntılamalar yapılmıştır.

Tablo 2

Araştırmada Oluşturulan Tema ve Alt Temalar

\begin{tabular}{ll}
\hline Tema & Alt Tema \\
\hline & Frrsat \\
1. Kazanç & Motivasyon \\
& Illşski \\
\hline \multirow{2}{*}{ 2. Güçlük } & Tecrübe \\
\hline \multirow{3}{*}{ 3. Gelecek Planları } & Olumsuz Duygular \\
& Sorumluluk \\
\hline
\end{tabular}

\section{Kazanç Teması Altında Fırsat Alt Teması}

Yatılı okullarda öğrencilere yönelik firsatların fazla olduğunu ifade eden katılımcılar ( $n=12)$ bu firsatlardan eğitim anlamında öğretmenlerin de faydalandıklarını ifade etmişlerdir. Katılımcılardan (E7), "Öğrencilere yönelik materyal zenginliği, laboratuvar, kütüphane ve bilgisayar odası gibi fırsatlar var, veriliyor. Öğretmenler de eğitim alanında bunlardan yararlanabiliyor." şeklinde görüş belirtmiştir. Yatılı okullarda ödenek gelirlerinin yüksek olduğuna dikkat çeken katılımcılar bunun çok büyük avantaj sağladığını, okulda materyal, spor salonu malzemeleri, laboratuvar, akıllı tahta, projeksiyon, bilgisayar odası gibi imkanlarının olduğunu bu avantajların da iş doyumlarını arttırdığını söylemişlerdir. Branşı beden eğitimi olan (S12) adlı katılımcı bu imkânlarla ilgili olarak "Spor malzemelerimiz ve spor salonumuz her şeyimiz mevcut. Yatılı okulların bütçesi gayet iyi” diyerek görüşünü paylaşmıştır. Katılımcılar ( $\mathrm{n}=9$ ) nöbet ve belleticilik ücreti ve ek hizmet puanı almalarının da önemli bir kazanç olduğu ifade etmişlerdir. (T1) adlı katılımcı ise "Yatılı okulun tek kazancı nöbet tutmanın getirdiği bir maddi ek gelir. Başka da bir kazancı yok" demiştir. 


\section{Kazanç Teması Altında Motivasyon Alt Teması}

Öğretmenlerin büyük çoğunluğu $(n=15)$ motivasyon kaynağı olarak öğrencileri görmüş ve öğrencilerden aldıkları dönütlerin kendilerini motive ettiğini ifade etmişlerdir. $\mathrm{Bu}$ öğretmenler öğrencilerin mutluluğunu, hayallerini ve mezun olan öğrencilerin kazandıkları başarıları en büyük kazanç olarak görmüştür. (B5) adlı katılımcı "Öğrencilerimin bir yerlere geldiğini görmek, iyi bir insan yetiştirmek ve dua almak en büyük motive kaynağım. İşte benim doyumumu arttıran şeyler bunlar." diyerek kendi motivasyon kaynağını belirtmiştir. (G10) adlı katılımcı da benzer olarak "Anlattı̆̆ım şeylerin öğrencilerde hayat bulması benim motivasyon kaynağım" demiştir. Az sayıda katılımcı (n=2) dışsal motivasyon kaynağına ihtiyacı olduğunu ifade etmiştir. (N11) adlı katılımcı "Başarının" (N14) ise "Takdir görmenin" kendilerini motive ettiğini dile getirmişlerdir.

\section{Kazanç Teması Altında İlişki Alt Teması}

Katılımcıların bazıları $(\mathrm{n}=4)$ yatılı okulların bir ev ortamı havasına sahip olduğunu belirtmişlerdir. (M2) adlı katılımcı yatılı okullarda iş birliğinin önemine değinerek "Yatılı okulda veliler, öğretmenler, memurlar, personeller, öğretmenler, öğrenciler herkes bir aile. Yatılı okulda herkes elini taşını altına koymakta." demiştir. Bazı katılımcılar $(n=7)$ yatılı okullarda yaşanan güçlüklerin öğretmenler arasındaki ilişkiyi daha güçlü ve sıkı hale getirdiğini ifade etmişlerdir. Okul yöneticileriyle ve diğer öğretmenlerle iyi ilişkilere sahip olan öğretmenlerin $(n=9)$ iş doyumlarını daha yüksek algıladıkları görülmüştür.

\section{Kazanç Teması Altında Tecrübe Alt Teması}

Katılımcı öğretmenlerin çoğu $(\mathrm{n}=13)$ yatılı okulda çalışmanın kendilerine tecrübe kazandırdığını ifade etmiştir. Katılımcılardan (E7) "Bu okulda öğretmenlik yapmak bize tecrübe katıyor burada bir yıl çalışmak diğer okullarda 23 yıl çalışmaya bedel." demiştir. Yatılı okula yeni atanan öğretmenlerin tecrübe eksikliği yaşadığını ve bu durumun da iş doyumunu azalttı̆̆ını ifade eden (H6) adlı katılımcı "Ben buraya gelmeden önce yatılı okullar hakkında hiçbir fikrim yoktu. Bizlere bilgilendirme yapılması lazım. Yoksa başlangıçta çok zorluk çekiyoruz" demiştir. Katılımcıların bir kısmı $(n=5)$ yatılı okulda görev yapacak olan öğretmenlere yönelik hizmet içi eğitimlerin verilmesinin öneminden bahsetmiştir. Bu katılımcılar öğretmenlerin eğitimler sayesinde daha kolay tecrübe kazanacaklarına ve iş doyumlarının daha yüksek olacağına inanmaktadır.

\section{Güçlük Teması Altında Olumsuz Duygular Alt Teması}

Özellikle yurtta gece nöbeti/belleticilik görevi olan öğretmenlerin okula daha mutsuz geldikleri ( $\mathrm{n}=15)$ görülmüştür. Katılımcılar okuldaki bahçe ve koridor nöbetleri ile pansiyonda tutulan gece nöbetlerinin kendilerini duygusal yönden yıprattığını ifade etmişlerdir. Bununla ilgili olarak (İ18) adlı katılımcı "Okuldan çıkınca üstümden dozer geçmiş gibi, kamyona kafa atmış gibiyim. Okuldan huzursuz ve bitkin ayrılıyorum." diyerek duygularını ifade etmiştir. (N11) adlı katılımcı da benzer bir görüş paylaşarak "Yatılı okulda çalışma koşulları zor. Özellikle çalışma saatleri, nöbet saatleri. Hele hele gece pansiyonda kalmak çok zor. Tüm bunlar insanın canını sıkıyor" diyerek görüşünü paylaşmıştır. Verilen yanıtlara göre yatılı okullarda çalışan özellikle de gece nöbet görevi olan öğretmenlerin mutsuzluk, huzursuzluk ve can sıkıntısı gibi duygular yaşadıkları anlaşılmıştır.

\section{Güçlük Teması Altında Sorumluluk Alt Teması}

Katılımcılardan bazıları (n=9) yatılı okuldaki en büyük güçlüğün sorumluluk noktasında olduğunu söylemişlerdir. Öğretmenlerin $(n=8)$ öğrencilere ait özel sorunlar dâhil birçok problemle doğrudan ilgilendikleri ve aile hasreti çeken öğrencilere anne-baba gibi davrandıkları görülmüştür. Böylece öğretmenliğin yanında ebeveynlik sorumluluğunu da taşıdıkları anlaşılmıştır. Katılımcılar yatılı okullarda mesai kavramının olmadığını ve tüm gün okuldan sorumlu olduklarını söylemişlerdir $(\mathrm{n}=4)$. Konuyla ilgili (S17) "Aklımız hep okulda. Hele de nöbetçi olduğumuzda 24 saat okulun her şeyinden sorumluyuz. Evde olsak da aklımız gene okulda ve yaşadığımız problemleri düşünüyoruz. 
$\mathrm{Bu}$ durum bazı zamanlar gündelik yaşamımıza da yansımıyor değil.” diyerek iş doyumunu azaltan nedenleri ifade etmiştir. Nöbet tutulan günün ardından derse girme sorumluluğunun da olduğunu dile getiren (M13) isimli katılımcı "Pansiyon nöbetinden sonra hiç dinlenemeden derslere girmek zorundayız. Bu aşırı derecede yorgunluğa sebep oluyor" demiştir.

\section{Gelecek Planları Teması Altında Okul Değiştirme Alt Teması}

Katılımcıların yarısı $(\mathrm{n}=9)$ öğretmenlik yaşamının geri kalan kısmında yatılı okulları bir daha tercih etmeyeceğini ve tayin isteyeceğini belirtmiştir. Katılımc1 (G10) bu durumu şöyle ifade etmiştir: "Yatılı okulda çalışmak bana birçok yönden fayda ve tecrübe sağladı ama bir daha tercih etmeyi düşünmüyorum." Katılımc1 (T1) ise "Çocuğum olduğundan dolayı belletmenlik görevi ve yoğunluk nedeniyle yatılı okulu bir daha düşünmem" demiştir.

Yatılı okulda görev yapmaya devam edeceğini ifade eden katılımcılar $(\mathrm{n}=9)$ bu tür okulların ek hizmet puanı, gece nöbeti ücreti gibi kazançlarından dolayı okul değiştirmeyi düşünmediklerini söylemişlerdir. (M2) adlı katılımcı "Tayin istesem bile gene yatılı okulu tercih ederim. Biz talip olmazsak bu çocuklara kim eğitim verecek sorumluluk almalıyız. Bu çocuklarla bir arada olmak benim doyumumu sağlayan en büyük güç" diyerek görüş belirtmiştir.

\section{Gelecek Planları Teması Altında Meslek Değiştirme Alt Teması}

Katılımcıların bir kısmı (n=5) uygun bir fırsat yakaladıkları takdirde öğretmenlik mesleğini bırakabileceğini ifade etmiştir. Bu öğretmenlerin iş doyumlarının daha düşük olduğu görülmüştür. Ancak katılımcıların çoğunluğu (n=13) başka bir meslek yapmayı düşünmediğini belirtmişlerdir. (Z9) adlı katılımcı bu konudaki fikrini şöyle ifade etmiştir: "Başka bir meslek mi? Ben bu meslek için yaratıldım ve öğretmen olarak öleceğim!”.

\section{Gelecek Planları Teması Altında Emeklilik Alt Teması}

Katılımcıların emeklilik konusundaki düşünceleri; aile ve çocuklarıyla vakit geçirme $(n=2)$, dinlenme $(n=3)$, geçim sıkıntısı $(n=2)$, sağlık sorunları $(n=2)$ ve ölüme yaklaşmak $(n=2)$ gibi olguları barındırmaktadır. Katılımcıların bir kısmı $(\mathrm{n}=4)$ faydalı olamayacaklarını ve kendilerini geliştiremeyeceklerini anladıkları zaman emekli olmaya karar vereceklerini söylemişlerdir. Katılımcılardan (M2) ise emekliliği şu şekilde ifade etmiştir: "Emeklilik daha çok çalışma anlamına geliyor. Emeklilik yatmak değildir. Vakıflar kurulabilir, sosyal hizmetlerde bulunulabilir, insanlara yardım edilebilir". (S12) adlı katılımcı ise "Emeklilik... ölüme bir adım daha yaklaşmak... sağlık sorunları... sağlık kaygıları. Yaşamın sonlarını herhalde hastanede geçiririz" şeklinde görüş̧ belirtmiştir. Katılımcıların emeklilik kavramını iş doyumuna bağlı olarak değerlendirmediği görülmüştür. Genellikle emeklilik yaşı geldiğinde emekli olacağını düşünen öğretmenlerin bir kısmı $(n=9)$ emekliliği oldukça olumsuz bir dönem olarak algılamaktadır.

\section{Sonuç, Tartışma ve Öneriler}

$\mathrm{Bu}$ araştırmada yatılı okullarda çalışan ve yurtta gece nöbeti tutan/belleticilik görevi olan öğretmenlerin iş doyumları nitel araştırma yöntemiyle incelenmiştir. Yapılan analizler sonucu 3 tema (Kazanç, Güçlük ve Gelecek Planları) ve bu temalara ait 9 alt tema (Fırsat, Motivasyon, İlişki ve Tecrübe; Olumsuz Duygular ve Sorumluluk; Okul Değiştirme, Meslek Değiştirme ve Emeklilik) oluşturulmuştur.

Yatılı okulların iş ve işleyişleri ile bu okullarda çalışan öğretmenlerin görev ve sorumlulukları diğer okullara göre büyük farklılık göstermektedir. Bunların başında gece nöbetleri/belleticilik görevleri ve öğrencilerin ailelerinden ayrı kalmaları gibi etmenler gelmektedir. Öğretmenlerin görev yaptıkları okul türüne göre iş doyumları değiştiği (Adıgüzel vd., 2011) bilinmektedir. Yatılı okullarda görev yapan öğretmenlerin diğer öğretmenlere göre iş doyumları daha düşük (Çelik, 2017) ve tükenmişlikleri daha fazladır (Gündüz, 2006; Özkaya, 2006). 
$\mathrm{Bu}$ araştırmada yatılı okullarda görev yapan öğretmenlerin okula hevesli geldikleri ancak gece nöbeti olan öğretmenlerin okula gelirken isteksiz ve moralsiz oldukları görülmüştür. Öğretmenler yatılı okullarda farklı sorun ve sorumluluklarının olduğundan bahsetmişlerdir. Bunların başında gece nöbetleri/belleticilik görevleri ve ailesinden uzakta olan öğrencilere bir ebeveyn gibi davranmak zorunda kalmaları gelmektedir. Tüm bu sorunların da öğretmenlerin iş doyumunu azalttığı görülmektedir. Alanyazında benzer sonuçlar ortaya koyan Çelik (2017), Dağlı ve Gündüz (2008), Eraslan (2006), İnal ve Sadık (2014), Kazu ve Aşkın (2011) ve Yılmaz (2009) gece nöbetlerinin yatılı okullarda görev yapan öğretmenlerin iş doyumunu azaltan en önemli faktörlerden biri olduğunu ifade etmişlerdir. Gökyer (2011) ve Şenol ve Y1ldız (2009) da yatılı okullarda çalışan öğretmenlerin anne babalara ait görevleri üstlenmek zorunda kaldıklarını ve fazla sorumluluklarının olduğunu dile getirmişlerdir. İnal ve Sandık (2011) bu okullardaki öğrencilerin öğretmenlerini abla, ağabey, anne ve baba olarak gördügünü ifade etmiştir. Skaalvik ve Skaalvik (2017) ile benzer bir sonuç olarak bu araştırmada da artan iş yükü ve sorumlulukların öğretmenlerin iş doyumunu azalttığ 1 ve duygusal olarak tükenmesine yol açtığı görülmektedir.

Araştırma bulgularına göre yatılı okullarda görev yapan öğretmenlerin iş doyumunu arttıran birçok faktör de bulunmaktadır. Bunların başında; zorlukların yanında tecrübe kazanmaları, materyallerin tam olması, okulun maddi imkânlarının geniş olması, iş birliğinin güçlü olması, belleticilik ve nöbet ücretlerinin ek bir gelir oluşturması ve ek hizmet puanı kazanmaları gelmektedir. Alanyazında da öğretmenlerin iş doyumunu arttıran faktörlerin arasında alınan ek ücretler (Arı, 2015; Kılıç, 2011; Taiwo, Eyarefe ve Olawale, 2019) ve okulun olumlu fiziksel şartlarının (Koruklu, Feyzioğlu, Kiremit ve Aladağ, 2013) yer aldığı görülmektedir. Bunun yanında öğretmenlerin aldıkları düşük ücret ve imkânlarının yetersizliği gibi iş doyumlarını azaltan faktörler de bulunmaktadır (Kachhawa, Joshi ve Gajraj, 2018; Özdemir, 1986).

Öğretmenler kendileri için en büyük motivasyon kaynağının öğrenciler olduğunu dile getirmişlerdir. Çoğunlukla içsel motivasyon kaynağına sahip olan öğretmenlerin takdir görme ve başarılı olma gibi isteklerinin de olduğu görülmüştür. Bu araştırmayla benzer bir sonuca ulaşan Çelik (2017) içsel tatmin kaynağı arayan öğretmenlerin daha yüksek iş doyumuna sahip olduklarını ifade etmiştir. Arifin (2015) ise iş ortamındaki motivasyonun iş doyumu için oldukça önemli bir faktör olduğunu dile getirmiştir.

Bu araştırmada öğretmenler; öğrenci, öğretmen, veli, okul yöneticisi ve diğer personellerin bir arada bulunduğunu, birçok konuda iş birliği yaptığını ve yatılı okulların bir aile ortamına sahip olduğunu ifade etmişlerdir. Bu aile ortamını hissetmenin de iş doyumlarını arttırdığını dile getirmişlerdir. Bu araştırma bulgusunu destekleyen nitelikte alanyazında birçok araştırma mevcuttur. Okulda diğer öğretmenlerle nitelikli ilişkilere sahip olan (Koruklu vd., 2013; Taiwo vd., 2019) ve okul yöneticileriyle iletişimi iyi olan (Arı, 2015; Başaran ve Güçlü, 2018; Bogler ve Nir, 2015; Nyenyembe, Maslowski, Nimrod ve Peter, 2016; Olsen ve Huang, 2019) öğretmenlerin iş doyumları daha yüksektir.

Yatılı okullardaki öğretmenler firsat ve imkânlarının yüksek olduğunu düşünmektedirler. Ancak yatılı okulların farklı sorumluluk ve işleyişinin olmasından dolayı bu öğretmenler yatılı okullarla ilgili bir eğitim almanın gerekliliğinden bahsetmişlerdir. Ayrıca yatılı okullarda çalışan ve deneyim açısından yetersiz olan öğretmenlerin iş doyumlarının daha düşük olduğu görülmüştür. Gökyer (2011) ve Yılmaz'a (2009) göre yatılı okullarda görev yapan öğretmenler mesleki kıdem açısından genellikle deneyimsiz öğretmenlerdir. Bu da yatılı okullarda öğretmenlerin işini zorlaştıran ve iş doyumunu azaltan bir başka faktördür. Yatılı okullarda görev yapan öğretmenlerin öncesinde bir eğitim almaları ve dolayısıyla bu okullarda daha tecrübeli öğretmenlerin çalışması önemlidir (Kazu ve Aşkın, 2011). Aynı zamanda benzer hizmet içi eğitimlere katılan öğretmenlerin iş doyumları bu tür eğitimlere katılmayanlara oranla daha yüksektir (Koruklu vd., 2013).

Araştırmaya göre öğretmenlerin bir daha yatılı okulda çalışıp çalışmama konusunda kararsız kaldıkları görülmüştür. Gece nöbeti, yorgunluk ve fazla sorumluluk gibi güçlüklerden dolayı yatılı okulda bir daha çalışmayacaklarını söyleyenlerin yanında; ek hizmet puanı ve belleticilik ücreti gibi 
kazançlarından ötürü farklı yatılı okullarda çalışabileceğini söyleyen öğretmenler de vardır. Benzer bir sonuç olarak Yılmaz (2009) da yatılı okulda bir daha çalışıp çalışmama sorusu karşısında ögretmenlerin dengeli cevaplar verdiğini ortaya çıkarmıştır. Ancak Arı (2002) yapmış olduğu çalışmada yatılı okullarda çalışan öğretmenlerin çoğunluğunun bir daha yatılı okulda çalışmak istemediği sonucuna ulaşmıştır.

$\mathrm{Bu}$ araştırmada yatılı okullarda çalışan öğretmenlerin birçoğu meslek değiştirmek istemediğini, kendilerini meslekleriyle uyumlu gördügünü ve mesleklerinde mutlu olduğunu belirtmişlerdir. Mesleğinde mutlu olan ve kendisini mesleğiyle uyumlu olarak algıllayan öğretmenlerin iş doyumlarının daha yüksek çıktığı görülmüştür. Yılmaz'a (2009) göre öğretmenlerin büyük çoğunluğu mesleğini isteyerek ve severek seçmiştir. Mesleğini severek yapan öğretmenlerin iş doyumu daha yüksektir (Üzümcü ve Müezzin, 2018). Bunun yanında genel bir çerçeveden bakıldığında öğretmenlerin birçoğunun iş doyumu oldukça yüksektir (Kılıç, 2011).

Alanyazındaki benzer konuda yapılmış araştırmalardan farklı olarak bu çalışma nitel araştırma yöntemiyle yapılmış ve konuyla ilgili daha derinlemesine bilgi sağlamıştır. Ancak bu avantajının yanında bazı sınırlılıkları da mevcuttur. Araştırma nitel araştırma yöntemiyle yapıldığı için katılımcı sayıs1 azdır ve araştırmanın genellenebilirliği düşüktür. Benzer bir araştırma hem nicel hem nitel araştırma yöntemini içeren karma araştırma yöntemiyle de yapılabilir. Bu araştırma Sivas'a bağlı bir ilçede yatılı okullarda görev yapan ilkokul, ortaokul ve lise öğretmenlerini kapsamaktadır. Benzer bir araştırma Türkiye'nin farklı bölgelerindeki yatılı okullarda çalışan öğretmenler ile yapılabilir. Ayrıca bu çalışmanın öğretmenlere yönelik olduğu düşünüldügünde yatılı okullarda görev yapan okul yöneticilerinin iş doyumunu inceleyen nitel araştırma yöntemine dayalı çalışmalar da yapılabilir.

\section{Kaynakça}

Adıgüzel, Z., Karadağ, M. ve Ünsal, Y. (2011). Fen ve teknoloji öğretmenlerinin iş tatmin düzeylerinin bazı değişkenlere göre incelenmesi. Batı Anadolu Eğitim Bilimleri Dergisi, 2(4), 49-74.

Agho, A., Mueller, C. and J. Price (1993). Determinants of employee job satisfaction: An emprical test of causal model. Human Relations, 46(8), 1007-1027.

Altınkurt, Y. ve Yılmaz, K. (2014). Öğretmenlerin mesleki profesyonelliği ile iş doyumları arasındaki ilişki. Sakarya Üniversitesi Ĕgitim Fakültesi Dergisi, 4(2), 57-71.

Altunkeser, F. ve Ünal, E. (2015). Sınıf öğretmeni adaylarının öğretmenlik mesleğine ilişkin tutumlarının çeşitli değişkenler açısından yordanması. Ahi Evran Üniversitesi Sosyal Bilimler Enstitüsü Dergisi, 2(1), 1-15.

Aralpcan, H. (1998). Yatıl ilköğretim bölge okulları'nın sayısal gelişimi ve hizmet sunduğu çevre. Yüksek Lisans Tezi. Ankara Üniversitesi, Sosyal Bilimler Enstitüsü, Ankara

Arı, A. (2002). Normal, taşımalı ve yatılı ilköğretim okullarının karşılaştırılması. Milli Eğitim Dergisi, 1(11), 153-154.

Arı, E. (2015). Öğretmenlerin iş doyumlarının mesleki tükenmişlik üzerine etkisinin yapısal eşitlik modeli ile araştırılması. Journal of International Social Research, 8(39), 549-565.

Arifin, H. M. (2015). The influence of competence, motivation, and organisational culture to high school teacher job satisfaction and performance. International Education Studies, 8(1), 38-45.

Aslan, E. ve Erbay, E. (2017). Ankara Aile ve Sosyal Politikalar il müdürlüğüne bağlı çocuk evlerinde çalışan bakım elemanları ve çocuk evi sorumlularının iş doyumu ve tükenmişlik düzeyleri. Türkiye Sosyal Araştırmalar Dergisi, 2, 535-556. 
Bakioğlu, A. ve Göktaş, E. (2018). Bir eğitim politikası belirleme yöntemi: Meta analiz. Medeniyet Eğitim Araştırmaları Dergisi, 1(2), 35-54.

Başaran, İ. E. (2000). Örgütsel davranış. Ankara: Feryal Yayınevi.

Başaran, M. ve Güçlü, N. (2018). Okul yöneticilerinin yönetim biçimleri ile öğretmenlerin iş doyumları arasındaki ilişkinin incelenmesi. Gazi Üniversitesi Gazi Ĕgitim Fakültesi Dergisi, 38(3), 949-963.

Bogler, R. and Nir, A. E. (2015). The contribution of perceived fit between job demands and abilities to teachers' commitment and job satisfaction. Educational Management Administration and Leadership, 43(4), 541-560.

Çalışkan, N. ve Ayık, A. (2015). Okul aile birliği ve velilerle iletişim. Ahi Evran Üniversitesi Sosyal Bilimler Enstitüsü Dergisi, 1(2), 69-82.

Çelik, N. (2017). Yatılı bölge ortaokulları ile diğer devlet okullarında çalışan ögretmenlerin iş tatmin düzeylerinin karşılaştırılması. Yüksek Lisans Tezi. Erzincan Üniversitesi, Sosyal Bilimler Enstitüsü, Erzincan.

Çelikkanat, C. (2000). Örgütlerde güdülenme ve iş doyumu. (1. Baskı). Ankara: Anı Yayıncılık.

Çokluk, Ö. (2003). Yönetimde çağdaş yaklaşımlar uygulamalar ve sorunlar. (2. Baskı). Ankara: Anı Yayıncilik.

Çoruk, A. ve Çicek, H. K. (2017). İlköğretim okullarında görev yapan öğretmenlerin okul yaşam kalitesi algıları ile iş doyumu algıları arasındaki ilişki. Dicle Üniversitesi Ziya Gökalp Ĕgitim Fakültesi Dergisi, (31), 750-761.

Dağl1, A. ve Gündüz, H. (2008). Yatılı ilköğretim bölge okullarında görev yapan yönetici ve öğretmenlerin tükenmişlik düzeyleri (Diyarbakır ili örneği). Dicle Üniversitesi Ziya Gökalp Eğitim Fakültesi Dergisi, (10), 12-35.

Demirtaş, Z. ve Nacar, D. (2018). Öğretmenlerin iş doyumu ve örgütsel sessizlik algıları arasındaki ilişki. Ĕgitim Yansımaları, 2(1), 13-23.

Eraslan, L. (2006). Yalnızlı̆ğn okullarl YIBBO'lar. 08.11.2019 tarihinde http://www.memurlar.net/haber/38102/ adresinden erişilmiştir.

Gedik, A. ve Üstüner, M. (2017). Eğitim örgütlerinde örgütsel bağl1lık ve iş doyumu ilişkisi: Bir meta analiz çalışması. E-Uluslararası Eğitim Araştırmaları Dergisi, 8(2), 41-57.

Gill, F. (1999). The meaning of work: Lessons from sociology, psychology and political theory. Journal of Socio-Economics, 6(28), 725-743.

Gökyer, N. (2011). Yatılı ilköğretim bölge okullarının sorunlarına ilişkin öğrenci ve öğretmen görüşleri. Buca Eğitim Fakültesi Dergisi, 7, 288-310.

Gündüz, H. (2006), Yatılı ilkögrretim bölge okullarında görev yapan yönetici ve ögretmenlerin tükenmişlik düzeyleri. Yüksek Lisans Tezi. Dicle Üniversitesi, Sosyal Bilimler Enstitüsü, Diyarbakır.

İnal, U. ve Sadık, F. (2011). Adana ili sınırları içerisindeki yatılı ilköğretim bölge okullarında bulunan öğrenci ve öğretmenlerin okul yaşam kalitesi algılarının incelenmesi. Çukurova Üniversitesi Sosyal Bilimler Enstitüsü Dergisi, 20(2), 243-258. 
İnal, U. ve Sadık, F. (2014). Yatılı ilköğretim bölge okullarının okul yaşam kalitesine ilişkin öğretmen ve öğrenci görüşleri. Çukurova Üniversitesi Eğitim Fakültesi Dergisi, 43(2), 169-194.

İşgör, I. Y. and Haspolat, N. K. (2016). Investigating the psychological well-being and job satisfaction levels in different occupations. International Education Studies, 9(12), 194-205.

Jackson, S. E., Schwab, R. L. and Schuler, R. S. (1986). Toward an understanding of the burnout phenomenon. Journal of Applied Psychology, 71(4), 630-640.

Johnson, B. and Christensen, L. (2014). Eğitim araştırmalarl nicel, nitel ve karma yaklaşımlar. (4. Bask1). Ankara: Eğiten Kitap.

Kachhawa, P. S., Joshi, A. and Gajraj, A. (2018). An assessment of teacher's job satisfaction and its possible effects on student achievements. Indian Journal of Positive Psychology, 9(1), 152154.

Kazu, İ. Y. ve Aşkın, Z. (2011). Yatılı ilköğretim bölge okullarının etüt saatlerinde ve boş zaman etkinliklerinde karşılaşılan sorunlar (Elazığ ili örneği). Pegem Ĕgitim ve Öğretim Dergisi, 1(3), 39-46.

Keser, A. (2005). İş tatmini ve yaşam tatmini ilişkisi: Otomotiv sektöründe bir uygulama. Çalışma Toplum Ekonomi ve Hukuk Dergisi, 7, 77-96.

Kılıç, Ö.S. (2011). İlkögrretim okullarında görev yapan okul müdürü ve ögretmenlerin iş doyumu (Tokat ili örneği). Yüksek Lisans Tezi. Selçuk Üniversitesi, Eğitim Bilimleri Enstitüsü, Konya.

Koruklu, N., Feyzioğlu, B., Kiremit, H. Ö. ve Kaldırım, E. (2013). Öğretmenlerin iş doyumu düzeylerinin bazı değişkenlere göre incelenmesi. Mehmet Akif Ersoy Üniversitesi Ĕgitim Fakültesi Dergisi, 1(25), 119-137.

Locke, E. A. (1976). The nature and causes of job satisfaction. In M. D. Dunette (Ed.), Handbook of Industrial And Organizational Psychology. Chicago: RandMcNally.

MEB (2010). Hoş geldin ögretmenim. İstanbul: Milli Eğitim Basımevi.

MEB (2011). Yatılı ilköğretim bölge okulları süreci iç denetim raporu. 05.09.2019 tarihinde meb.gov.tr adresinden erişilmiştir.

MEB (2016). Millı̂ Ĕgitim Bakanlı̆̆ına bağlı resmi okullarda yatılılık, bursluluk, sosyal yardımlar ve okul pansiyonları yönetmeliği. 09.11.2019 tarihinde ogm.meb.gov.tr adresinden erişilmiştir.

MEB (2020). Millî Ĕgitim istatistikleri yayınlanmıştır (Örgün eğitim 2019/2020). 07.11.2020 tarihinde http://sgb.meb.gov.tr/ adresinden erişilmiştir.

Nyenyembe, F. W., Maslowski, R., Nimrod, B. S. and Peter, L. (2016). Leadership styles and teachers' job satisfaction in Tanzanian public secondary schools. Universal Journal of Educational Research, 4(5), 980-988.

Okumuş, M. (2011). Öğretmenlerde meslek tatmini ve işstresi. İstanbul: Özgü Yayınları.

Olsen, A. and Huang, F. (2019). Teacher job satisfaction by principal support and teacher cooperation: Results from the schools and staffing survey. Education Policy Analysis Archives, 27(11), 131. 
Özdemir, S. (1986). Kamu ödeme sistemi içinde öğretmen ücretlerinin yeri ve sağladı̆ğ doyum. Yüksek Lisans Tezi. Ankara Üniversitesi, Ankara.

Özkaya, H. (2006), Yatılı ilkögretim bölge okulları ve ilköğretim okullarında görev yapan ögretmenlerin tükenmişlik düzeylerinin öğretmen görüş̧leri açısından karşılaştırılması, Yüksek Lisans Tezi. 18 Mart Üniversitesi, Sosyal Bilimler Enstitüsü, Çanakkale.

Robbins, S. P. ve Judge, T. (2012). Örgütsel Davranış. (Çev. Ed. İ. Erdem), Ankara: Nobel Akademik Yayincilik.

Skaalvik, E. M. and Skaalvik, S. (2017). Motivated for teaching? Associations with school goal structure, teacher self-efficacy, job satisfaction and emotional exhaustion. Teaching and Teacher Education, 67, 152-160.

Şenol, D. ve Yıldız, S. (2009). Yatılı ilköğretim bölge okullarında öğrenci-öğretmen ve aile etkileşimiDiyarbakır ve Erzurum örneği. Çukurova Üniversitesi Sosyal Bilimler Enstitüsü Dergisi, 18(1), 359-376.

Taiwo, O. O., Eyarefe, I. D. and Olawale, S. S. (2019). Job satisfaction as correlate of teachers'job performance in public secondary schools in Osun State. Educational Research International, $8(3), 81-89$.

Üzümcü, B. ve Müezzin, E. E. (2018). Öğretmenlerin bilişsel esneklik ve mesleki doyum düzeyinin incelenmesi. Sakarya University Journal of Education, 8(1), 8-25.

Vural, B. (2004). Yetkin-ideal-vizyoner ögretmen. İstanbul: Hayat Yayınları.

Yılmaz, E. ve Aslan, S. (2017). Lise öğretmenlerinde tükenmişlik, iş doyumu ve algılanan sosyal destek: Bursa ili örneği. Abant İzzet Baysal Üniversitesi Eğitim Fakültesi Dergisi, 18(3), 18611886.

Yılmaz, M. (2009). Yatıl ilkögrretim ve ortaögretim okullarında görev yapan ögretmen ve idarecilerin iş tatmin düzeyleri ile tükenmişlik düzeylerinin karşılaştırılması (İnebolu ilçesi örneği). Yüksek Lisans Tezi. Yeditepe Üniversitesi, Sosyal Bilimler Enstitüsü, İstanbul. 


\section{Extended Abstract}

\section{Introduction}

The society needs well-educated individuals in many areas. The basic way for the development of society and individuals is education. The biggest actors of education are teachers. Teachers with high job satisfaction play an important role in the development and progress of society (Adigüzel, Karadağ and Ünsal, 2011; Karakaya-Çiçek and Çoruk, 2017). In order to provide information exchange and communication in educational institutions, the school environment should be based on trust. The quality of education is lower in educational institutions where job satisfaction are low levels (İşgör and Haspolat, 2017). The low level of job satisfaction in the educational environment may indirectly harm the educational environment, students, parents and the whole society (Çokluk, 2003, p.109). For teachers, the concept of job satisfaction is expressed as satisfaction and dissatisfaction of teachers with their profession (Vural, 2004, p.32). Jackson, Schwab and Schuler (1986) stated the factors affecting job satisfaction in teachers as follows: Economic conditions, working hours, stress, relations with administrators and working conditions.

Distribution of population in our country is unbalanced and scattered. There are many villages, hamlets and plateau where transportation is difficult. Especially in Southeastern Anatolia, Eastern Anatolia and Black Sea regions, there are some obstacles in terms of climate and geography. This situation causes children under compulsory education to be unable to attend schools. Boarding schools were opened for the education of the students in the villages where the population is scattered and small (MoNE [Ministry of National Education], 2011). Today, some educational institutions have dormitory opportunities. The students live in these dormitories, not in their homes where away from their schools, and they can go home during holidays. Students in boarding schools live away from their families and experience some difficulties. Therefore, the responsibilities and awareness levels of the teachers working in boarding schools are very important (MoNE, 2010, p.229). Job satisfaction of teachers working in boarding schools may be more important than job satisfaction of teachers in other schools. The teachers have the night duty, they spend all the night at the dormitory and spend 24 hours with the students who are away from their families (Çelik, 2017).

When the literature is examined, it is seen that there are researches about the job satisfaction of teachers (Ar1, 2015; Başaran and Güçlü, 2018; Çelik, 2017; Demirtaş and Nacar, 2018; KarakayaÇiçek and Çoruh, 2017; Koruklu, Feyzioğlu, Kiremit and Aladağ, 2013; Yılmaz and Aslan, 2018). However, it is seen that quantitative research methods were used in most of the researches. In this study, qualitative research method was used to examine the boarding schools and teachers working in these schools which have been an important issue in education for many years.

\section{Purpose}

The aim of this study is to investigate job satisfaction levels of teachers working in boarding schools. Teachers' feelings, thoughts and attitudes towards boarding school, profession, and the future were examined in this research. It is thought that this study will make significant contribution to the literature on job satisfaction of teachers working in boarding schools.

\section{Method}

This research was designed as a phenomenology of qualitative research methods. The study group of the study consisted of 18 teachers working in boarding schools in a district of Sivas in 20182019 academic year. The study group of the study was determined by purposive sampling method. The criteria determined in the selection of teachers; working in boarding schools and having night duty In the data collection, a semi-structured interview form consisting of 17 questions was used. 


\section{Findings}

Content analysis was performed in analyzing the data. As a result, three themes (1. Gain, 2. Difficulty and 3. Future Plans) and nine related sub themes were created. The nine themes created are: (1) Opportunity, Motivation, Relationship, Experience; (2) Negative Emotions, Responsibility; (3) Change of School, Change of Occupation and Retiring.

\section{Discussion and Conclusion}

The functioning of boarding schools and the duties and responsibilities of teachers working in these schools are very different from other schools. The main differences are the night shifts and the students who are away from their families. It is known that job satisfaction varies by the type of school in which teachers work (Adigüzel et al., 2011). The teachers who work in boarding schools have lower job satisfaction (Çelik, 2017) and have more exhausted (Gündüz, 2006; Özkaya, 2006). In this study, it was seen that the teachers working in boarding schools come to school enthusiastically, but they who has night duty are reluctant and depressed. The teachers stated that they have different problems and responsibilities in boarding schools.

The main problems are the night duties in dormitory and to treat students as their parents. It is seen that all these problems reduce the job satisfaction of teachers. In the literature, Çelik (2017), Dağlı and Gündüz (2008), Eraslan (2006), İnal and Sadık (2014), Kazu and Aşkın (2011) and Yılmaz (2009) showed similar results. According to them, night duty is one of the most important factors that decrease the job satisfaction of teachers working in boarding schools. According to the research findings, there are many factors that increase the job satisfaction of teachers working in boarding schools. The main factors are these: Experience against difficulties, complete materials, financial facilities, side income with night duty, additional duty scores. According to literature, among the factors that increase teachers' job satisfaction; side income (Arı, 2015; Kılıç, 2011; Taiwo, Eyarefe and Olawale, 2019) and positive physical opportunity of the school (Koruklu, Feyzioğlu, Kiremit and Aladağ, 2013) are observed. 